\title{
The Manatee in British Honduras
}

\author{
By John Charnock-Wilson
}

The West Indian manatee Trichechus manatus manatus has declined rapidly in many parts of its range and appears on the IUCN's list of endangered species. But in British Honduras last summer the author found an abundance of manatees all along the coast. Moreover, predation is at a minimum: the people who formerly ate manatee meat now show little interest in it, and the alligator, its only other predator, has been persecuted almost to extinction.

B

RITISH HONDURAS, on the west side of the Caribbean Sea, has an irregular coastline of some 200 miles, protected for most of its length by a barrier reef and numerous coral and mangrove islands, which are known locally as cayes and drowned cayes respectively (channels between drowned cayes are called bogues). The water between the coast and the reef is fairly calm and up to 25 feet deep, with no appreciable current or tidal flow. The coast is mostly mangrove swamp with coconut-fringed sandy beaches and dry land near the river mouths, and the manatees find shelter in the numerous rivers, creeks and lagoons opening to the sea. Behind the coast, the mangrove extends inland in places up to five miles, relieved in the north by open flat pine ridge (savanna) and in the south by mountains and virgin forest. The rivers are up to 200 miles long, sluggish in the north with headwaters in the hinterland, often with lagoons and lakes along their course, but in the south, where the rainfall is greatest, amounting to 200 inches a year, shorter, fast-flowing and rock-strewn.

The drowned cayes with their bogues and lagoons inside provide sanctuary and feeding grounds for the manatees, while the shallow coastal waters with abundant eel-grass on the bottom provide further feeding grounds. The water in both rivers and coastal waters alike is clear except in times of flood.

Observations in the summer of 1967, while travelling in British Honduras, and close questioning of local people, seem to show that manatees inhabit all the coastal waters, both the sea itself, the lagoons and the rivers up to quite some distance from their mouths. They appear to be equally at home in fresh or salt water, but do not traverse fast-flowing water or occur above rapids. At sea they favour sheltered water, and I found them in creeks and bogues between the drowned cayes. I found none at Turneffe Island, a large drowned caye, sheltered, quiet and isolated, but some 20 miles off-shore and only to be approached across deep and often rough waters. There are manatees in the several fresh and saltwater lagoons connected with the sea, notably Manatee Lagoon.

Under normal conditions all that is seen of the manatee is a small black snout some six inches out of the water, a dark shadow or a trail of muddy water. Local people believe that, with its broad, flat, rounded tail, the manatee is capable of a speed up to 30 m.p.h., but no actual measurements are known. One phenomenon mentioned by many people was the animal's 
ability to 'roll' itself up and down gently sloping banks, like a barrel. No photographs of this were produced, and I did not see it myself. The manatees I saw made no noise except for the low whistle normally associated with heavy breathing; descriptions by informants ranged from a 'snoring or snorting' to 'a low whistle'.

Hearsay evidence, corroborated by several informants, suggested that mating takes place for the most part in April but also in August, (the driest months). Apparently as many as a dozen animals, which are relatively fearless when approached, congregate together and then move as a herd into shallow water and begin to pair off, making a commotion and disturbance in the water. The pairs then drag themselves half out of the water and embrace lying on their sides. After this they return to the water and again play vigorously as a herd before dispersing. The entire courtship and mating takes some 10 to 15 minutes.

Young calves, it was said, were seen with their mothers mostly in the wet months, September through to March. The majority spoke of seeing single calves although twins were also reported, but in unknown proportions. The most popular position during nursing appears to be with the calf beside its mother suckling at the pectoral teat. One or two people referred to the mother floating upright in the water and clasping the calf in a human fashion, but the majority thought that she lay either on her back or belly during suckling. It was also stated that sometimes a calf would be supported by the female on her back.

Any estimate as to the numbers of manatees in British Honduras is no more than guesswork; but that there are plenty is beyond question. Many Europeans travelling about the country mentioned seeing them. Herds of half-a-dozen were often seen from the air, and one informant referred to two to be seen on many afternoons in the sea in front of his house. They seem to be on almost every stretch of suitable water. The manatee is not adapted at all to defending itself, but it has few enemies in British Honduras. Alligators, which may have killed the young in the past, have been persecuted almost to extinction, and purposeful hunting by man now seems to be rare. In the past isolated communities may have eaten the animal, but now the whole population has access to domestic fresh, salted and tinned meat, and the younger generation has not acquired the taste for manatee. Many old people referred to eating it often in their youth but had not done so in recent years. Altogether, prospects seem good for the species in British Honduras.

\section{REFERENCES}

BERTRAM, COLIN. In Search of Mermaids: The Manatees of Guiana. London 1963.

BERTRAM, C. \& C. Status of the manatees in the Guianas. Oryx VII, p. 90.

\section{Conservation Pays}

The first legal sale of northern sea otter skins since 1911, when the stocks hap sunk so low that hunting was banned, brought a record bid of $\$ 2,300$ ( $£ 958$ ) each for four skins, paid by a Dallas department store. 